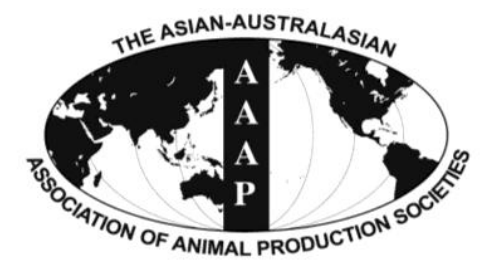

Asian Australas. J. Anim. Sci.

Vol. 26, No. 12 : 1762-1772 December 2013

http://dx.doi.org/10.5713/ajas.2013.13141

www.ajas.info

pISSN 1011-2367 elSSN 1976-5517

\title{
The Effects of Pre-slaughter Stress and Season on the Activity of Plasma Creatine Kinase and Mutton Quality from Different Sheep Breeds Slaughtered at a Smallholder Abattoir
}

\author{
A. Y. Chulayo and V. Muchenje* \\ Department of Livestock and Pasture Science, Faculty of Science and Agriculture, \\ University of Fort Hare, P Bag X 1314, Alice, 5700, South Africa
}

\begin{abstract}
The objective of the current study was to determine the effect of pre-slaughter stress, season and breed on the activity of plasma creatine kinase (CK) and the quality of mutton. One hundred and seventy-three (173) castrated sheep from Dormer (DM), South African Mutton Merino (SAMM), Dorper (DP) and Blackhead Persian (BP) sheep breeds were used in the study. The animals were grouped according to age-groups as follows: Group 1 (6 to 8 months), Group 2 (9 to 12 months) and Group 3 (13 to 16 months). Blood samples were collected during exsanguinations using disposable vacutainer tubes for CK analysis. Representative samples of the Muscularis longissimuss thoracis et. lumborum (LTL) were collected from 84 castrated sheep, of different breeds (28 per breed) $24 \mathrm{~h}$ after slaughter. The following physico-chemical characteristics of mutton were determined; meat $\mathrm{pH}\left(\mathrm{pH}_{24}\right), \mathrm{color}\left(\mathrm{L}^{*}, \mathrm{a}^{*}\right.$ and $\left.\mathrm{b}^{*}\right)$, thawing and cooking losses and Warner Braztler Shear Force (WBSF). The activity of plasma CK was significantly higher ( $<<0.001)$ in summer $(1,026.3 \pm 105.06)$ and lower in winter $(723.3 \pm 77.75)$. There were higher values for $L^{*}(33.7 \pm 0.94), b *(11.5 \pm 0.48)$ and WBSF $(29.5 \pm 1.46)$ in summer season than in winter season; $\mathrm{L}^{*}(29.4 \pm 0.64), \mathrm{b}^{*}(10.2 \pm 0.33)$ and WBSF $(21.2 \pm 0.99)$. The activity of plasma CK was influenced by the type of breed with Dormer having the highest $(\mathrm{p}>0.001)$ levels $(1,358.6 \pm 191.08)$ of CK. South African Mutton Merino had higher values for $\mathrm{pH}_{24}(5.9 \pm 0.06), \mathrm{L}^{*}(34.2 \pm 0.97), \mathrm{b}^{*}(12.2 \pm 0.50)$ and WBSF (26.8 \pm 1.51$)$ and Blackhead Persian had higher values (35.5 \pm 2.17$)$ for cooking loss (CL\%) than the other breeds. Computed Principal Component Analyses (PCA) on the activity of plasma $\mathrm{CK}$ and physico-chemical characteristics of mutton revealed no correlations between these variables. However, positive correlations were observed between $\mathrm{pH}_{24}, \mathrm{~L}^{*}, \mathrm{a}^{*}, \mathrm{~b}^{*}, \mathrm{CL} \%$ and WBSF. Relationships between pre-slaughter stress, CK activity and physico-chemical characteristics of mutton were also observed. It was therefore concluded that although mutton quality and creatine kinase were not related, pre-slaughter stress, season and breed affected the activity of creatine kinase and mutton quality. (Key Words: Abattoir, Enzymes, Color, Meat pH, Temperature, Tenderness)
\end{abstract}

\section{INTRODUCTION}

Sheep are important in the communal areas of Eastern Cape, South Africa as they are a source of cash, milk, wool and meat (Mapiliyao et al., 2012). The province has the highest (30\%) meat consumption percentage of meat that is consumed locally (DAFF, 2010). Of the 95 abattoirs found in Eastern Cape Province of South Africa, more than 50\% of them are classified as smallholder (low throughputs) abattoirs (ECRMA, 2012). Thirty percent of the meat that is consumed locally comes from the smallholder abattoirs. However, not much work has been documented about the

\footnotetext{
* Corresponding Author: Voster Muchenje. Tel: +27-40-6022059, Fax: +27-86-628-2967, E-mail: vmuchenje@ufh.ac.za Submitted Mar. 5, 2013; Accepted Jun. 8, 2013; Revised Jul. 21, 2013
}

quality of mutton produced under practical conditions with reference to pre-slaughter stress. Information that relates to the effect of pre-slaughter stress on mutton quality has been conducted under experimental designs (Lowe et al., 2001; Miranda-de la Lama et al., 2010a). Pre-slaughter stress is caused by the activities such as the period of collecting the animals in preparation for loading at the farm, loading and off-loading, transportation of animals to the abattoir and lairage period at the abattoir (Adzitey, 2011). It is influenced by the animal's previous experiences and specific features observed at the farm and at the lairages (Muchenje et al., 2009; Dodzi and Muchenje, 2011; Ndou et al., 2011).

Stress reactions are adaptive; they help the animal to cope with the novelty of the environment by inducing physiological and behavioral changes (lactate, glucose, 
plasma creatine kinase "CK" and cortisol) in the animal (Terlouw, 2005; Gregory, 2010). Some of the pre-slaughter stress factors like ambient temperature, transportation, distance and lairage duration (Adzitey, 2011) leads to fatigue (Warriss et al., 1998), cause animals to release enzymes and hormones (creatine kinase, cortisol and catecholamines (De Haan et al., 1995; Terlouw, 2005; Muchenje et al., 2009) into the blood stream leading to a series of secondary processes that involve energy metabolism, respiratory function, immune function and osmotic regulation (Hoffman et al., 1998; Ali et al., 2006). Fatigue can be observed in sporting activities, but in animals it can be induced by repeated short contractions of the muscle which causes internal muscle damage. These internal muscle damages are difficult to identify in sheep due to the long and soft wool they possess (Kannan et al., 2000; Ali et al., 2006). Furthermore, fatigue results in the depletion of glycogen reserves in the muscles causing an increase in lactic acid production post mortem, which subsequently increases meat $\mathrm{pH}\left(\mathrm{pH}_{24}\right)$ (Terlouw and Rybarczyk, 2008; Veiseth-Kent et al., 2010).

Increased use of ATP give rise to the activity of the enzyme called creatine kinease; CK (Allen et al., 1995). Creatine Kinase is found in the skeletal muscles of animals, responsible for maintaining energy homeostasis at the sites of high Adenosine TriPhosphate (ATP) (Dieni and Storey, 2009). The activity of CK found in plasma or serum is used to diagnose muscular damage in many species (Hamburg et al., 1991; Hornikova et al., 2009). When CK is found in the blood plasma, it indicates muscle damage (Sáncheza et al., 1999). Rupture of muscles causes the release of CK which is deposited into the blood (Vojtic, 2000). Total activity of CK can also be used to measure the sum of enzyme activities from different organs of the animal. It was noted that $\mathrm{CK}$ can either be an $\mathrm{M}$ or a $\mathrm{B}$ monomer subunit. Muscle creatine kinase (M-CK) which can also be denoted by $\mathrm{S}-\mathrm{CK}$ is found in the M-line of the H-zone of the sarcomere length (Brancaccio et al., 2007; Hornikova et al., 2009). Therefore, the presence of CK in the blood indicates muscle exertion by adverse conditions and poor sheep welfare during the pre-slaughter period (Tadicha et al., 2005).

Pre-slaughter stress such as loading and bullying of animal by others (animal characteristics) has a negative impact on the eating quality of meat (Vimiso and Muchenje, 2013) such as $\mathrm{pH}$, color, thawing loss, cooking loss and WBSF values (toughness of meat). Animal-related characteristics include breed, age, gender and health status of the animal (van Heerden et al., 2007; Sainsbury et al., 2011). Hopkins and Fogarty (1998), Toohey and Hopkins (2006) and Rodríguez et al. (2011) reported that diverse lamb genotype, fattening of suckling lamb under commercial and controlled conditions have a negative effect on the carcass quality and eating quality of mutton. However, there is limited information regarding the activity of CK and physico-chemical characteristics of mutton as affected by pre-slaughter stress, season and type of breed under practical conditions. Therefore, the objective of the current study was to determine the effect of pre-slaughter stress, season and type of breed on the activity of CK and the quality of physico-chemical characteristics of mutton from different sheep breeds slaughtered at a smaller holder abattoir.

\section{MATERIALS AND METHODS}

\section{Description of the study}

The study was carried out at Adelaide Nxuba local municipal abattoir located $32^{\circ} 8^{\prime} \mathrm{S}$ and $26^{\circ} 9^{\prime} \mathrm{E}$ in the Amathole District of the Eastern Cape Province, South Africa. Adelaide is located at $586 \mathrm{~m}$ above sea level. It is also situated in the semi-arid False Thornveld of the Eastern Cape. The temperatures in Adelaide during the period of study were ranging from $15^{\circ} \mathrm{C}$ to $36^{\circ} \mathrm{C}$ with mean temperatures of $21.5^{\circ} \mathrm{C}$.

\section{Study animals}

The study was conducted under practical conditions at a small-holder municipal abattoir. Data were collected as animals were brought in for slaughter. No attempt was made to control the activities happening during process; this includes both pre-slaughter stress and animal-related characteristics (breed, age and sex). One hundred and seventy-three (173) sheep that were presented for slaughter at the abattoir between winter (March - August 2010) and summer (September - March 2011) seasons were used. Among those slaughtered, 4 different breeds (Dormer, South African Mutton Merino, Dorper and Blackhead Persian) of sheep were identified. The number of animals per breed was as follows; 15 Dormer, 46 South African Mutton Merino, 77 Dorper and 35 Blackhead Persian. The animals used were castrates with overall slaughter weight of approximately 39.5 to $40 \mathrm{~kg}$. The animals were brought to the abattoir for slaughter once they attained weights varying between 39.5 or $40 \mathrm{~kg}$.

\section{Transportation}

The animals were transported by light duty vehicles from different farms to the abattoir. The average size of each vehicle was $3.6 \mathrm{~m} \times 4.4 \mathrm{~m}$ with the stocking density of $0.75 \mathrm{~m}^{2}$, approximately 3 units of sheep (during the summer season) to 4 units of sheep (during the winter season). One unit of sheep is equivalent to 5 sheep, therefore in summer 15 animals were transported per load and in winter 20 animals were transported per load. The stocking density was calculated by dividing the floor area by the number of 
animals in the vehicle and the density was expressed as animals $/ \mathrm{m}^{2}$. Departure time from the farm, distance travelled and lairage duration were recorded. On arrival at the abattoir, sheep were given water ad-libitum prior to slaughter. The average daily temperature after transportation was obtained from Adelaide town weather records. A record sheet was used to capture all the records.

\section{Biochemical/physiological determination of blood}

Blood collection and plasma separation: An electric stunner of 650 Volts was used for five seconds to make the sheep are unconscious. The sheep were suspended by their hind leg and a sharp knife was used to cut the throat to allow bleeding. They were allowed to bleed for $6 \mathrm{~min}$. During exsanguination blood was collected from each sheep while they were still hanging, after cutting of the throat. Disposable vacutainer tubes containing anticoagulant Ethylenediaminetetraacetic acid (EDTA) were used to collect blood samples. Blood sample from each animal was labeled accordingly and kept in ice until plasma was separated within $2 \mathrm{~h}$ after collection. Blood samples were centrifuged at $21^{\circ} \mathrm{C}$ for $10 \mathrm{~min}$ at 3,550 rpm placed in 1.5 $\mathrm{mL}$ Eppendorf tubes and stored at $-20^{\circ} \mathrm{C}$ (Model 5403 Centrifuge, Gatenbay Eppendorf $\mathrm{GmbH}$, Engelsdorp, Germany) to separate plasma from the blood. The samples were then arranged in a rack and marked to correspond to the type of breed it was collected from.

Creatine Kinase $(C K)$ activity determination: The activity of plasma CK was analyzed at National Health Laboratory Services, Port Elizabeth (South Africa) using Model DXC 600 machine (Beckman Coulter, Ireland) with reactive ingredients for SYCHRON Systems (CK 2*200). The ingredients were added for quantitative determination of CK activity of units per liter (U/L) in plasma. The contents included 2* 61ML CK Reagent, 1 Preparation insert and the reactive ingredients included Creatine Phosphate, Disodium Salt $461 \mathrm{mmol} / \mathrm{L}$, Nadide 30:0 $\mathrm{mmol} / \mathrm{L}$, Adenosine-5-Diphosphate, Monopotassium Salt, Dihydrate $36.0 \mathrm{mmol} / \mathrm{L}$, Glucose $24.0 \mathrm{mmol} / \mathrm{L}$, Glucose-6Phosphate Dehydrogenase 46.1 kU/L and Hexokinase 136 $\mathrm{kU} / \mathrm{L}$.

\section{Meat quality measurements}

Representative samples of the Muscularis longissimuss thoracis et. lumborum (LTL) were collected from 84 castrated sheep of different breeds (28 South African Mutton Merino, 28 Dorper and 28 Blackhead Persian). No meat sample was collected for Dormer since the owner of the animals wanted the whole carcass without any cuts from the animals where meat samples were collected. The muscle was removed by cutting a sample between the 4th and 6th ribs $(14 \times 9 \times 3 \mathrm{~cm})$ of the loin region while the carcasses were still hanging. The collected samples were used for the measurements of $\mathrm{pH}_{24}$, color $\left(\mathrm{L}^{*}, \mathrm{a}^{*}\right.$, and $\left.\mathrm{b}^{*}\right)$, thawing and cooking losses and Warner Braztler Shear Force (WBSF) of meat. The weight of the meat samples ranged from 191 to 210 g. Each sample was vacuum-packed, kept in a cooler box an hour after collection and further stored in the refrigerator at $-4^{\circ} \mathrm{C}$.

pH measurements: A portable $\mathrm{pH}$ meter, with a fibreoptic probe (CRISON pH 25 Instruments SA, Alella, Spain) was used to measure $\mathrm{pH}$ of the meat $24 \mathrm{~h}$ post mortem. It was measured from the Muscularis longissimuss thoracis et. lumborum muscle removed from the hanging carcasses. The $\mathrm{pH}_{\mathrm{u}}$ meter was first calibrated using $\mathrm{pH} 4, \mathrm{pH} 7$ and $\mathrm{pH} 9$ standard solutions (CRISON Instruments, SA, Spain). The measurements were then performed with a sharpened metal sheath to prevent probe breakage. The values of $\mathrm{pH}_{24}$ were recorded accordingly.

Determination of meat color: The color of meat $\left(\mathrm{L}^{*}=\right.$ lightness, $\mathrm{a}^{*}=$ redness and $\mathrm{b}^{*}=$ yellowness) (Commission International De I' Eclairage, 1976) was determined at the butchery $24 \mathrm{~h}$ after slaughter from the muscle samples removed on the hanging carcasses and transported from the abattoir. A portable refrigerator vehicle was used to move carcasses from the abattoir to the butchery an hour after slaughter. After cutting the sample from the carcass, a Minolta color-guide 45/0 BYK-Gardener GmbH machine with a $20 \mathrm{~mm}$ diameter measurement and illuminant D65day light, $10^{\circ}$ standard observer was used for color measurement. The machine was calibrated each day before taking measurements using the green, black and white standard color samples provided for this purpose. The readings were taken by rotating the Color Guide $90^{\circ}$ between measurements so as to obtain the average value for the color.

Determination of WBSF, thawing and cooking losses of mutton: On average, after $21 \mathrm{~d}$, the Muscularis longissimuss thoracis et. lumborum muscle samples were removed from refrigeration, weighed, then thawed and weighed again. The recorded weight differences were expressed as the thawing loss using the following formulae:

$$
\begin{aligned}
& \text { Thawing loss } \% \\
& =[(\text { weight from freezer-weight after thawing }) \\
& \quad /(\text { weight from freezer })] \times 100 \%
\end{aligned}
$$

The meat samples were placed in a plastic bag and cooked using water bath at $85^{\circ} \mathrm{C}$ for $45 \mathrm{~min}$ (Ding et al., 2010). Cooking loss was then calculated using the following formulae:

Cooking loss $\%$

$=[($ weight before cooking - weight after cooking $)$ /(weight before cooking) $] \times 100 \%$ 
Tenderness of mutton was determined using the InstronWarner-Bratzler Shear Force (WBSF) machine. After cooking, 3 sub samples of specified $10 \mathrm{~mm}$ core diameter were cored parallel to the grain of the meat. The samples were sheared perpendicular to the fiber direction using a Warner Bratzler (WB) shear device mounted on an Instron (Model 3344) Universal Testing apparatus (cross head speed at $400 \mathrm{~mm} / \mathrm{min}$, one shear in the centre of each core). The mean of maximum load $(\mathrm{N})$ was recorded for each batch.

\section{Statistical analysis}

Generalized Linear Models procedure of SAS (2003) was used to determine the effect of breed, age and season on CK activity. The following model was used:

$$
\mathrm{y}_{\mathrm{ijk}}=\mu+\alpha_{\mathrm{i}}+\beta_{\mathrm{j}}+\varepsilon_{\mathrm{ijk}}
$$

Where, $\mathrm{y}_{\mathrm{ijk}}=$ Response variable $(\mathrm{CK}$ activity and mutton quality characteristics)

$\mu=$ Overall mean,

$\alpha_{i}=$ Breed effect (Blackhead Persian, Dorper, Dormer and SA Mutton Merino breeds),

$\beta_{\mathrm{j}}=$ Seasonal effects (summer and winter season),

$\varepsilon_{\mathrm{ijk}}=$ Random error term.

Pair-wise comparison of means was done using the LSD method. The relationship between continuous variables, CK and physico-chemical characteristics of mutton were analyzed using PROC Regression model of SAS (2003) to determine the $\mathrm{CK}$ and physico-chemical characteristics of mutton. The following model was used:

$$
y=a+b_{1} X_{1}+b_{2} X_{2}+b_{3} X_{3}+b_{4} X_{4}
$$

Where, $\mathrm{y}=$ Response variable $\left(\mathrm{CK}, \mathrm{pH}_{24}, \mathrm{~L}, \mathrm{a}^{*}, \mathrm{~b}^{*}\right.$, Thaw \%, CL\% and WBSF),

$\mathrm{a}=$ Intercept,

$\mathrm{b}=$ Co-efficient variable,

$\mathrm{X}=$ Continuous variables (Temperature, Transport time, Lairage duration and Stocking density. The Principal Component Analysis (PCA) was also used to determine the relationship between $\mathrm{CK}$ and physico-chemical characteristics of mutton.

\section{RESULTS AND DISCUSSION}

Effect of season on the activity of CK and physicochemical characteristics of mutton

Table 1 shows the effects of season on the activity of plasma CK and physico-chemical characteristics of mutton. An increased $(\mathrm{p}<0.001) \mathrm{CK}$ activity $(1,026.3 \pm 105.06)$ was observed in summer than in winter season. During the summer season, $\mathrm{CK}$ production increased as a result of the
Table 1. Least square mean values $( \pm \mathrm{SE})$ for creatine kinase, ultimate $\mathrm{pH}$, color and cooking loss $\%$ and WBSF of mutton as affected by season for all breeds

\begin{tabular}{lccc}
\hline \multirow{2}{*}{ Parameter $^{1}$} & \multicolumn{2}{c}{ Season } & $\begin{array}{c}\text { Significance } \\
\text { level }\end{array}$ \\
\cline { 2 - 4 } & Winter & Summer & $* * *$ \\
$\mathrm{pH}_{24}(\mathrm{U} / \mathrm{L})$ & $723.3 \pm 77.75$ & $1,026.3 \pm 105.06$ & $\mathrm{NS}$ \\
$\mathrm{L}^{*}$ & $5.7 \pm 0.04$ & $5.8 \pm 0.06$ & $* * *$ \\
$\mathrm{a}^{*}$ & $29.4 \pm 0.64$ & $33.7 \pm 0.94$ & $\mathrm{NS}$ \\
$\mathrm{b}^{*}$ & $16.3 \pm 0.60$ & $16.3 \pm 1.09$ & $*$ \\
$\mathrm{CL} \%$ & $10.2 \pm 0.33$ & $11.5 \pm 0.48$ & $\mathrm{NS}$ \\
WBSF (N) & $32.8 \pm 1.63$ & $31.3 \pm 2.37$ & $* * *$ \\
\hline
\end{tabular}

${ }^{1} \mathrm{CK}=$ Creatine kinase, $\mathrm{pH}_{24}=$ Meat $\mathrm{pH}, \mathrm{L}^{*}=$ Lightness, $\mathrm{a}^{*}=$ Redness, $\mathrm{b}^{*}=$ Yellowness, $\mathrm{WBSF}=$ Warner Bratzler Shear Force

Significant difference: $* \mathrm{p}<0.05$, $* * * \mathrm{p}<0.001$, NS $=$ No significance difference.

rapid respiration rate of the animal. In addition, increased levels of CK could be a result of physical activity at high temperatures that leads to muscular damage, including fatigue due to prolonged and intense muscle activity. Similar results were found by Kannan et al. (2000); Miranda-de la Lama et al. (2010a) and Miranda-de la Lama et al. (2012) where higher CK activity was as a result of stress associated with transportation during summer season in goats and lambs. The increase in CK could be attributed to an increase in ATP demand that is used to speed up respiration and metabolism during pre-slaughter stress (Chulayo and Muchenje, 2013). Pollarda et al. (2002) reported that, elevated activity of $\mathrm{CK}$ in red deer was due to transportation. However, lower CK activity in goats was reported by Zimerman et al. (2011) due to the summer season and adverse pre-slaughter conditions. During transportation, muscle enzyme activity increases as a result of increased muscle cell permeability or muscle cell damage. This makes CK a sensitive indicator of muscular damage and fatigue (Miranda-de la Lama et al., 2010b).

In Table $1, \mathrm{~L}^{*}(\mathrm{p}<0.001)$, Warner Bratzler Shear Force (WBSF) $(p<0.001)$ and $b^{*}(p<0.05)$ were affected by season because of the abrupt change in environmental temperatures in winter that lead to dark cutters. Seasonal changes have been reported to have a negative effect on the quality of pork (Rodríguez-Sánchez et al., 2009). It was also reported that season has an effect on mutton quality (María et al., 2006). Adverse pre-slaughter stressors are also known to negatively affect meat quality attributes such as color, tenderness and $\mathrm{pH}_{24}$ (Mazzone et al., 2010; Miranda-de la Lama et al., 2012). However, there were no significant $(\mathrm{p}>0.05)$ effects of season (Table 1 ) on $\mathrm{pH}_{24}$, redness $\left(\mathrm{a}^{*}\right)$ and cooking loss \% (CL\%) in the current study. Dalla Costa et al. (2007) reported negative impact of the winter season on the quality of pig meat. 
Pre-slaughter stress on the activity of CK and physicochemical characteristics of mutton

Table 2 shows a relationship between pre-slaughter stress and the activity of $\mathrm{CK}$ and physico-chemical characteristics of mutton. A positive linear relationship was observed between temperature and CK activity. The study also concurs with the findings of Melesse et al. (2011) who reported increased CK activity due to high temperatures. Partida et al. (2007) also reported that increasing environmental temperatures and pre-slaughter stress caused by loading, transportation and lairage duration also increased CK activity. According to Earley et al. (2012), longer hours of transportation are also a source of stress and it increases CK activity in the blood. During transportation, the truck stocking density did not have an effect on the animal since there was no muscle injury associated with stocking density. Miranda-de la Lama et al. (2012) reported fewer/no injuries associated with stocking density. However, in a moving truck and low stocking density, animals require more energy in order to keep themselves balanced. There was no relationship observed between pre-slaughter stressors such as distance, lairage duration, stocking density and enzyme $\mathrm{CK}$ activity.

A positive and negative linear relationship between temperature, distance and lairage duration on $\mathrm{pH}_{24}$ and $\mathrm{L}^{*}$, stocking density, lairage duration and temperature on $\mathrm{pH}_{24}$ and $\mathrm{b}^{*}$ and between distance duration and $\mathrm{a}^{*}$ were observed.
Pre-slaughter stress may result in lower glycogen levels which may lead to increased $\mathrm{pH}$ values from meat causing darker meat (Muchenje et al., 2008; Yu et al., 2009). The color of mutton is as a result extrinsic factors such as preslaughter conditions, slaughtering itself and oxygenation and oxidation processes during ageing which later affect color evolution (Jose et al., 2008). Increase in transportation time resulted in a decrease in lightness and yellowness of meat while redness and $\mathrm{pH}_{24}$ increases. Animals endure pain during long journeys because of fasting and exhaustion towards the end of the journey (Abril et al., 2001; Van de Water et al., 2003). Similarly, Lambertini et al. (2006) reported that the meat from rabbits was affected by preslaughter lairage duration and transportation. In addition, $\mathrm{L}^{*}$ and $\mathrm{b}^{*}$ are reduced while $\mathrm{a}^{*}$ values increases.

\section{The effect of breed on the activity of CK}

Table 3 shows significant breed effect on the activity of CK. Among the sheep breeds, Dormer had the highest activity of CK $(1,358.6 \pm 191.08)$ than Blackhead Persian

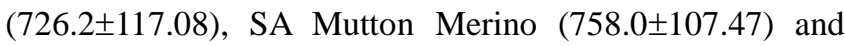
Dorper (656.3 \pm 81.79$)$. Dormer is a breed from Dorset Horn and Germany Merino bred to adapt to winter rainfall conditions of South Africa. Nevertheless, these breeds are indigenous breeds that can be raised under harsh conditions except for Dormer which is sensitive to rough handling. The hardiness of Dorper could also be indicated by the reduced

Table 2. Pre-slaughter stress (temperature, stocking density, lairage and distance duration) and their relationship with creatine kinase activity and physico-chemical characteristic of mutton

\begin{tabular}{|c|c|c|c|c|}
\hline Parameter $^{1}$ & Variable & Relationship & Equation & Significance \\
\hline \multirow[t]{4}{*}{$\overline{\mathrm{CK}}$} & Temperature $\left({ }^{\circ} \mathrm{C}\right)$ & Linear & $Y=16.27+8.330 x$ & $*$ \\
\hline & Distance duration $(\mathrm{km})$ & NS & $Y=-3.22+1.838 x$ & NS \\
\hline & Lairage duration (t) & NS & $Y=-0.43+0.472 x$ & NS \\
\hline & Stocking density $\left(\mathrm{LU} / \mathrm{m}^{2}\right)$ & NS & $Y=236.91+220.887 x$ & NS \\
\hline \multirow[t]{4}{*}{$\mathrm{pH}_{24}$} & Temperature $\left({ }^{\circ} \mathrm{C}\right)$ & Linear & $Y=0.02+0.006 x$ & $* * *$ \\
\hline & Distance duration $(\mathrm{km})$ & Linear & $Y=0.00+0.001 x$ & $* * *$ \\
\hline & Lairage duration $(\mathrm{t})$ & Linear & $Y=0.00+0.000 x$ & $* *$ \\
\hline & Stocking density $\left(\mathrm{LU} / \mathrm{m}^{2}\right)$ & Linear & $Y=0.61+0.17 x$ & $* * *$ \\
\hline \multirow[t]{4}{*}{$\mathrm{L}^{*}$} & Temperature $\left({ }^{\circ} \mathrm{C}\right)$ & Linear & $Y=-0.34+0.10 x$ & $* * *$ \\
\hline & Distance duration $(\mathrm{km})$ & Linear & $Y=-0.06+0.02 x$ & $*$ \\
\hline & Lairage duration $(\mathrm{t})$ & Linear & $Y=-0.02+0.006 \chi$ & $* * *$ \\
\hline & Stocking density $\left(\mathrm{LU} / \mathrm{m}^{2}\right)$ & NS & $Y=-5.54+3.065 x$ & NS \\
\hline \multirow[t]{4}{*}{$a^{*}$} & Temperature $\left({ }^{\circ} \mathrm{C}\right)$ & NS & $Y=0.08+0.049 x$ & NS \\
\hline & Distance duration $(\mathrm{km})$ & Linear & $Y=0.03+0.010 x$ & $* *$ \\
\hline & Lairage duration $(\mathrm{t})$ & NS & $Y=0.00+0.002 x$ & NS \\
\hline & Stocking density $\left(\mathrm{LU} / \mathrm{m}^{2}\right)$ & NS & $Y=-1.35+1.501 x$ & NS \\
\hline \multirow[t]{4}{*}{$b^{*}$} & Temperature $\left({ }^{\circ} \mathrm{C}\right)$ & Linear & $Y=-0.11+0.046 x$ & $*$ \\
\hline & Distance duration $(\mathrm{km})$ & NS & $Y=-0.00+0.010 x$ & NS \\
\hline & Lairage duration $(\mathrm{t})$ & Linear & $Y=-0.01+0.002 x$ & $* * *$ \\
\hline & Stocking density $\left(\mathrm{LU} / \mathrm{m}^{2}\right)$ & Linear & $Y=-3.07+1.411 x$ & $*$ \\
\hline
\end{tabular}

Significance difference: $* \mathrm{p}<0.05, * * \mathrm{p}<0.01, * * * \mathrm{p}<0.001, \mathrm{NS}=$ Not significant. $x=$ Temperature, Distance duration, Lairage duration, Stocking density.

${ }^{1} \mathrm{CK}=$ Creatine kinase, $\mathrm{pH}_{24}=$ meat $\mathrm{pH}, \mathrm{L}^{*}=$ Llightness, $\mathrm{a}^{*}=$ Redness, $\mathrm{b}^{*}=$ Yellowness 
Table 3. Least square means $( \pm \mathrm{SE})$ for the effect of Blackhead Persian, Dormer, Dorper and SA Mutton Merino breeds on Creatine Kinase activity

\begin{tabular}{lc}
\hline Breed & CK U/L at $* * * \mathrm{p}<0.001$ \\
\hline Blackhead Persian $(n=36)$ & $726.2 \pm 117.08^{\mathrm{a}}$ \\
Dormer $(n=78)$ & $1,358.6 \pm 191.08^{\mathrm{b}}$ \\
Dorper $(n=14)$ & $656.3 \pm 81.79^{\mathrm{a}}$ \\
SA Mutton Merino $(n=45)$ & $758.0 \pm 107.47^{\mathrm{a}}$ \\
\hline
\end{tabular}

$\overline{\mathrm{a}, \mathrm{b}}$ Means with different superscript in the same column are significantly different.

Significance difference: $* * * \mathrm{p}<0.001$.

$\mathrm{CK}=$ Creatine kinase. $n=$ Number of animals 3 .

$\mathrm{U} / \mathrm{L}=$ Units per liter.

CK activity that made it to withstand poor pre-slaughter conditions (Fourie et al., 2002). Even though these sheep are indigenous, $\mathrm{BH}$ is a fat-tailed breed whereas SAMM produces wool and meat (Almeida, 2011). Therefore, Dorper can be slaughtered during the summer months as it survives even under harsh conditions.

\section{The effect of breed on physico-chemical characteristics of mutton}

Table 4 shows the physico-chemical characteristics of mutton from the three breeds. Mutton from South African Mutton Merino had higher $(\mathrm{p}<0.001)$ values for $\mathrm{pH}_{24}$, $\mathrm{L}^{*}$ and $b^{*}$ than Dorper and Blackhead Persian sheep The differences observed between BP, DP and SAMM breeds for $\mathrm{pH}_{24}$ were anticipated because they are meat producing breeds even though they have other traits of economic importance such as for wool (SAMM) and fat (BP) production (Schoeman, 2000). In addition, the results obtained in the current study could be that SAMM is a late maturing breed as compared to DP (Webb and O'Neill, 2008). This is also due to the fact that type of breed is one of the factors that cause variation in meat quality (Sanudo et al., 1996). The results were not comparable to those of Teixeira et al. (2005) who found no differences on meat at
$24 \mathrm{~h}$ after slaughter. However, Cloete et al. (2008) found difference in $\mathrm{pH}_{24}$ when comparing Merino breed with other breeds of sheep. The $\mathrm{pH}_{24}$ from DP and SAMM were above the normal range of pH 5.4 and 5.7 (Hoffman et al., 2003) making the meat undesirable.

Higher levels of $\mathrm{pH}_{24}$ affect the conversion of muscles to meat because of reduced glycogen reserves and low lactic acid in the muscles after slaughter (Ferguson and Warner, 2008; Rodríguez et al., 2011). The $\mathrm{pH}_{24}$ of muscles is one of the contributing factors to the quality of meat because increased ultimate $\mathrm{pH}\left(\mathrm{pH}_{\mathrm{u}}\right)$ results to darker meat. The color of meat is what consumer use to charge the quality of meat and make purchasing decisions (Rani et al., 2013) extremely important indicator of red meat quality, smell and texture were regarded as more important quality indicators (Radder and Le Roux, 2005). It was also reported by Mach et al. (2008) that beef with $\mathrm{pH}_{24}$ above 6.0 is undesirable for human consumption because it leads to DFD (Dark Firm dry) meat. Dark Firm Dry meat is measured by $\mathrm{L}^{*}$ coordinate which also depends on differences in $\mathrm{pH}_{24}$ (Wiklund et al., 2003; Rodríguez et al., 2011). The darker meat (low $\mathrm{L}^{*}$ values) from Blackhead Persian may be attributed to reduced muscle glycogen and increased myoglobin content because of the light scattering properties of meat. The DFD meat is mostly due to transport stress and novelty of the environment.

The M. longissimus thoracis et. lumborum muscle from the SAMM breed was lighter as compared to DP and BP. The differences found between these breeds show that animals have different levels of susceptibility to stress especially the SAMM breed (Mota-Rojas et al., 2006). The higher $L^{*}$ value for SAMM is associated with the production of lactic acid prior to slaughter. Higher glycogen reserves credited other activities that occur post-mortem requiring energy such as breaking down the bond between muscle proteins to improve the tenderness of meat (Martinez-Cerezo et al., 2005). An increase in $\mathrm{pH}_{24}$ results

Table 4. Mean $( \pm \mathrm{SE})$ for $\mathrm{pH}_{24} \mathrm{~L}^{*}, \mathrm{a}^{*}, \mathrm{~b}^{*}, \mathrm{CL} \%$ and WBSF of mutton as affected by Blackhead Persian, Dorper and SA Mutton Merino

\begin{tabular}{|c|c|c|c|c|}
\hline \multirow{2}{*}{$\begin{array}{l}\text { Meat quality } \\
\text { characteristics }\end{array}$} & \multicolumn{4}{|c|}{ Breed } \\
\hline & Blackhead Persian & Dorper & SA MM & Significance level \\
\hline No. & 28 & 28 & 28 & \\
\hline $\mathrm{pH}_{24}$ & $5.6 \pm 0.06^{\mathrm{a}}$ & $5.8 \pm 0.05^{\mathrm{b}}$ & $5.9 \pm 0.06^{\mathrm{b}}$ & $* * *$ \\
\hline $\mathrm{L}^{*}$ & $28.8 \pm 0.86^{\mathrm{a}}$ & $31.7 \pm 0.82^{\mathrm{b}}$ & $34.2 \pm 0.97^{\mathrm{c}}$ & $* * *$ \\
\hline$a^{*}$ & $16.7 \pm 0.49$ & $17.2 \pm 0.47$ & $17.6 \pm 0.56$ & NS \\
\hline$b^{*}$ & $9.1 \pm 0.44^{\mathrm{a}}$ & $11.2 \pm 0.42^{\mathrm{b}}$ & $12.2 \pm 0.50^{\mathrm{b}}$ & $* *$ \\
\hline CL \% & $35.5 \pm 2.17^{\mathrm{b}}$ & $33.0 \pm 2.08^{\mathrm{a}}$ & $29.3 \pm 2.46^{\mathrm{a}}$ & $* * *$ \\
\hline WBSF & $22.9 \pm 1.33^{\mathrm{a}}$ & $26.4 \pm 1.28^{\mathrm{b}}$ & $26.8 \pm 1.51^{\mathrm{b}}$ & $* *$ \\
\hline
\end{tabular}

$\overline{\mathrm{a}, \mathrm{b}, \mathrm{c}}$ Means with the different superscript in the same row differ significantly.

Level of significance: $* * \mathrm{p}<0.01, * * * \mathrm{p}<0.001, \mathrm{NS}=$ Not significant.

$\mathrm{pH}_{24}=$ Meat $\mathrm{pH}, \mathrm{L}^{*}=$ Lightness, $\mathrm{a}^{*}=$ Redness, $\mathrm{b}^{*}=$ Yellowness, CL\% $=$ Cooking loss percentage, WBSF $=$ Warner Braztler Shear Force, SAMM $=$ South African Mutton Merino.

No $=$ Number of animals per breed 
in tougher meat as observed in SAMM. The WBSF values observed for BP could be attributed to the fact that this breed is a fat-tailed. Fat improves the tenderness of meat, and fat in meat contributes to the eating quality of mutton. There were no breed effects $(p>0.05)$ on $a^{*}$ values. The reason could be that color of meat can also be affected by chemical stability of myoglobin in the muscle (Kannan et al., 2001; Jacob et al., 2005; Muchenje et al., 2009). Myoglobin stability is also affected by electrical stimulation, chilling light exposure, diet (Vitamin E supplementation) and sex (Rosenvold and Andersen, 2003) which were not measured in the current study. Significant breed effects were observed in $\mathrm{CL}$ and WBSF values. The highest $(\mathrm{p}<0.001) \mathrm{CL}$ and $(\mathrm{p}<0.01)$ WBSF values were observed in meat from BP and SAMM, respectively. The meat from BP and DP was considered to be tender than that of SAMM. SA Mutton Merino had tougher meat and higher $\mathrm{pH}_{24}$. Increased tenderness could be due to the effects of $\mathrm{pH}_{24}$ activity on the proteolytic enzymes that degrade myofibrillar muscle structure (Wanatabe et al., 1996). In contrast, Miranda-de la Lama et al. $(2009,2011)$ reported increased tenderness of meat with higher $\mathrm{pH}_{24}$. However, Muchenje et al. (2008) indicated that higher $\mathrm{pH}_{24}$ may not always be involved in toughness of meat.

Correlations between the activity of CK and physicochemical characteristics of mutton

Figure 1 shows the PCA for correlations between CK and physico-chemical characteristics of mutton. Creatine kinase was not related to any of the meat quality parameters. However, Warriss et al. (1990) and Mach et al. (2008) reported that $\mathrm{CK}$ can be linked to muscle exhaustion that occurs prior to slaughter. In the current study, results show only values after slaughter as it was conducted under practical conditions where no manipulations are made to the animals according to treatment. This causes muscle damage, increased CK activity and negatively affects the quality of meat (Yu et al., 2009). According to Wiklund et al. (2003), muscles of the animal in good physical condition contain enough glycogen to guarantee optimal $\mathrm{pH}_{24}$ values (5.5 to $5.7)$ in the meat. Depletion of glycogen is due to the extent of transport and lairage duration (Liu et al., 2012). Positive correlations were observed between physico-chemical characteristics; $\mathrm{pH}_{24}, \mathrm{~L}^{*}, \mathrm{a}^{*}, \mathrm{~b}^{*}, \mathrm{CL} \%$ and WBSF. Higher $\mathrm{pH}_{24}$ found in the muscles was associated with darker meat (Miranda-de la Lama et al., 2009; Muchenje et al., 2009). The color of meat does not only depend on $\mathrm{pH}_{24}$ but on the type of muscle too (Jacob et al., 2007).

Meat $\mathrm{pH}_{24}$ affects other important meat quality attributes such as color, tenderness and water holding capacity (WHC) (Muchenje et al., 2008). According to Cloete et al. (2008), high $\mathrm{pH}_{24}$ has an effect on the color and tenderness of meat. It was also indicated that higher $\mathrm{pH}_{24}$ (>5.8) leads to undesirable beef color (Ferguson et al., 2001; Hoffman et al., 2003; Muchenje et al., 2009) and undesirable mutton color (Hopkins and Fogarty, 1998; Toohey and Hopkins; 2006) which is unattractive to the consumer (Vergara and Gallego, 2000; Esenbuga et al., 2009). Furthermore, the relationship between physicochemical characteristics is also dependent on the differences in intramuscular fat, $\mathrm{pH}_{24}$, cooling rate, muscle fiber and myoglobin. Moisture content in the muscle, cooking temperatures and the amount of water lost during cooking have been found to be contributing factors towards physicochemical characteristic (Combes et al., 2003; Kadim et al., 2008; Muchenje et al., 2008; Miranda-de la Lama et al.,

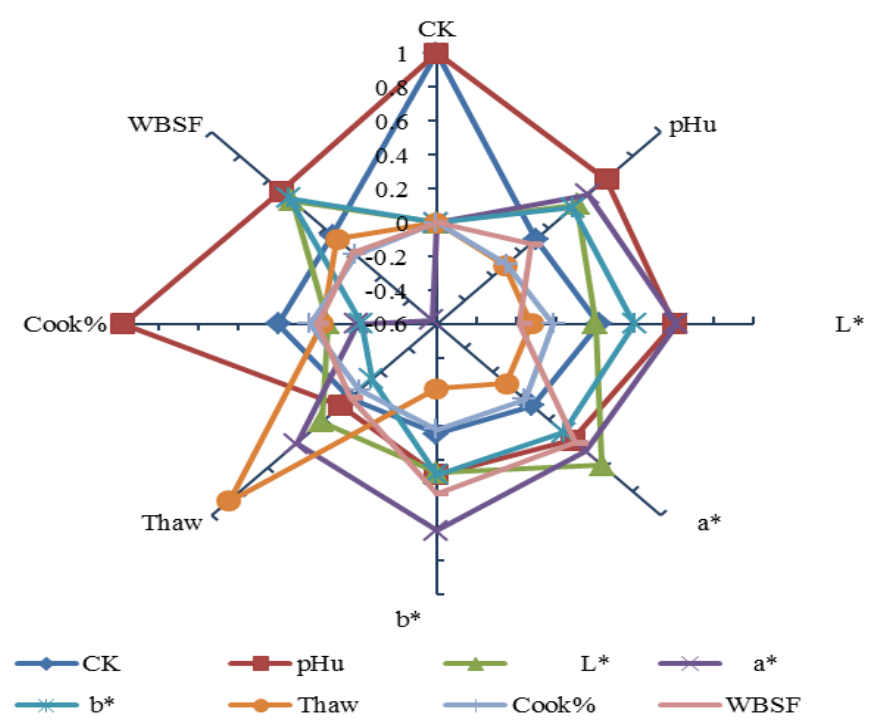

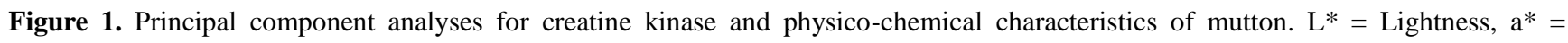
Redness, $\mathrm{b}^{*}=$ Yellowness, $\mathrm{pH}_{\mathrm{u}}=$ Meat $\mathrm{Ph}$, Cook $\%=$ Cooking loss, $\mathrm{CK}=$ Creatine kinase, Thaw $=$ Thawing loss percentage, $\mathrm{WBSF}=$ Warner Braztler Shear Force. 
Table 5. Principal component analyses results between the activity of creatine kinase and physico-chemical characteristics of mutton

\begin{tabular}{lrcc}
\hline Component & Eigenvalue & $\begin{array}{c}\text { Proportion of } \\
\text { variance }(\%)\end{array}$ & $\begin{array}{c}\text { Cumulative } \\
\text { variance }(\%)\end{array}$ \\
\hline 1 & $573,556.891$ & 99 & 99 \\
2 & 137.357 & 0.02 & 99 \\
3 & 48.883 & 0.01 & 99 \\
4 & 33.611 & 0.01 & 100 \\
\hline 1 = Creatine kinase, $2=\mathrm{pH}_{24} 3$ = Lightness $\left(\mathrm{L}^{*}\right), 4=\operatorname{Redness}\left(\mathrm{a}^{*}\right)$.
\end{tabular}

2009). Martinez-Cerezo et al. (2005) indicated that the differences in the physico-chemical characteristics of mutton are due to the activities that occur in the muscle. However, the characteristics of mutton differ in their importance as shown by PCA analyses (Kadim et al., 2009).

In the current study, as shown in Table 5, CK contributed a greater proportion of variance as compared to the meat quality characteristics. This implies that there is no relationship between $\mathrm{CK}$ and physico-chemical characteristics of mutton. In lamb, about $49.67 \%$ was explained by PCA for the first four meat quality characteristics (Cańeque et al., 2004). Kumar and Singh (2010) used PCA to analyze the main parameters that were responsible for the main variability in water. They reported about $94.5 \%$ of the factors explaining the total variability. As explained earlier, the second, third and fourth components $\left(\mathrm{pH}_{24}, \mathrm{~L}^{*}\right.$ and $\left.\mathrm{a}^{*}\right)$ were influenced by chemical compositions that include glycogen content in the muscle. However, it could not be determined which components did contribute to the indicated variances.

\section{CONCLUSION}

Meat quality and creatine kinase are negatively affected by pre-slaughter stress, season and breed. Summer affected the lightness, yellowness and tenderness of meat in increased the activity of CK. Meat for BP was tender than DP and SAMM with a decrease in $\mathrm{pH}_{24}$. Despite the fact that $\mathrm{CK}$ is a sensitive indicator of muscular damage and fatigue, it is not related to physico-chemical characteristics of mutton. Therefore, further studies are needed to identify the sources of variance for CK production and extent of muscular damage in relation to CK activity and physicochemical characteristics of mutton during pre-slaughter stress under practical conditions. In addition, there is a need to assess other stress related enzymes produced during preslaughter stress and their effect on the quality of mutton.

\section{ACKNOWLEDGEMENTS}

The authors acknowledge the National Research
Foundation (NRF, Project T079) of South Africa and Red Meat Research and Development Trust of South Africa (RMRDT-SA) for assisting in funding this research. Appreciation also goes to the municipal abattoir that allowed this study to be conducted on their premises.

\section{REFERENCES}

Abril, M., M. M. Campo, A. Önenç, C. Sañudo, P. Albertí, and A. I. Negueruela. 2001. Beef colour evolution as a function of ultimate $\mathrm{pH}$. Meat Sci. 58:69-78.

Adzitey, F. 2011. Effects of pre-slaughter animal handling on carcass and meat quality: Mini Review. Int. Food Res. J. 18:485-49.

Ali, B. H., A. A. Al-Qarawi, and H. M. Mousa. 2006. Stress associated with road transportation in desert sheep and goats, and the effect of pre-treatment with xylazine or sodium betaine. Res. Vet. Sci. 80:343-348.

Allen, D. G., J. Lännergren, and H. Westerblad. 1995. Muscle cell function during prolonged activity: Cellular mechanism of fatigue. Exp. Physiol. 80:497-527.

Almeida, A. M. 2011. The Damara in the context of Southern Africa fat-tailed sheep breeds. Trop. Anim. Health Prod. 43:1427-1441.

Brancaccio, P., N. Maffulli, and F. M. Limongelli. 2007. Creatine Kinase monitoring in sport medicine. Br. Med. Bull. 8182:209-230.

Cańeque, V., C. Pérez, S. Velasco, M. T. Díaz, S. Lauzurica, I. Álvarez, F. Ruiz de Huidobro, E. Onega, and J. De la Fuente. 2004. Carcass and meat quality of light lambs using principal component analysis. Meat Sci. 67:595-605.

Chulayo, A. Y. and V. Muchenje. 2013. Effect of pre-slaughter conditions on physico-chemical characteristics of mutton from three sheep breeds slaughtered at a smallholder rural abattoir. S. Afr. J. Anim. Sci. 43:S64-S98.

Cloete, J. J. E., L. C. Hoffman, and S. W. P. Cloete. 2008. Carcass characteristics and meat quality of progeny of five Merino dam lines crossed with Dormer and Suffolk sires. S. Afr. J. Anim. Sci. 38:355-366.

Commission International De I' Eclairage. 1976. Colorimetry (2nd Ed.).Vienna, Switzerland: CIE.

Dalla Costa, O. A. L. Faucitano, A. Coldebella, J. V. Ludke, J. V. Peloso, D. Dalla Roza, and M. J. R. Paranhos da Costa. 2007. Effects of the season of the year, truck type and location on truck on skin bruises and meat quality in pigs. Livest. Sci. 107:29-36.

De Haan, A. J. C. M. Koudijs, R. A. Wevers, and B. Wieringa. 1995. The effects of MM-Creatine deficiency on sustained force production of mouse fast skeletal muscle. Exp. Physiol. 80:491-494.

Department of Agriculture, Forestry and Fisheries (DAFF). 2010. A profile of the South African mutton market value chain. http://www.nda.agric.za/docs/AMCP/MuttonMVCP201011.pdf. Accessed: 17 March 2012.

Dieni, C. A. and K. B. Storey. 2009. Creatine Kinase regulation by reversible phosphorylation in frog muscle. Comp. Biochem. Phys. (Part B) 152:405-412.

Ding, W., L. Kou, B. Cao, and Y. Wei. 2010. Meat quality 
parameters of descendants by hybridization of boar and Guanzhong Dairy goat. Meat Sci. 84:323-328.

Dodzi, M. S. and V. Muchenje. 2011. Avoidance-related behavioural variables and their relationship to milk yield in pasture-based dairy cows. Appl. Anim. Behav. Sci. 133:11-17.

Eastern Cape Red Meat Abattoirs (ECRMA). 2012. http://www.nda.agric.za/vetweb/VPH/AbattoirLists/Red\%20M eat/Eastern\%20Cape\%20Red\%20Meat\%20Abattoirs.htm. Accessed: $17^{\text {th }}$ March 2012.

Earley, B., M. Murray, D. J. Prendiville, B. Pintado, C. Borque, and E. Canali. 2012. The effects of transport by road and sea on physiology, immunity and behaviour of beef cattle. Res. Vet. Sci. 92:531-541.

Esenbuga, N., M. Macit, M. Karaoglu, V. Aksakal, M. L. Aksu, M. A. Yoruk, and M. Gul. 2009. Effect of breed on fattening performance, slaughter and meat quality characteristics of Awassi and Morkaraman lambs. Livest. Sci. 123:255-260.

Ferguson, D. M., H. L. Bruce, J. M. Thompson, A. F. Egan, D. Perry, and W. R. Shorthose. 2001. Factors affecting beef palatability. Farmgate to chilled carcass. Aust. J. Exp. Agric. 41:879-891.

Ferguson, D. M. and R. D. Warner. 2008. Have we underestimated the impact of pre-slaughter stress on meat quality in ruminants? Meat Sci. 80:12-19.

Fourie, P. J., F. W. C. Neser, J. J. Olivier, and C. van der Westhuizen. 2002. Relationship between production performance, visual appraisal and body measurements of young Dorper rams. S. Afr. J. Anim. Sci. 32:256-262.

Gregory, N. G. 2010. How climatic changes could affect meat quality. Food Res. Int. 43:1866-1873.

Hamburg, R. J., D. L. Friedman, and M. B. Perryman. 1991. Metabolic and diagnostic significance of creatine kinase isoenzymes. Trends in Cardiovasc. Med. 1:195-200.

Hoffman, D. E., M. F. Spire, J. R. Schwenke, and J. A. Unruh. 1998. Effect of source of cattle and distance transported to a commercial slaughter facility on carcass bruises in mature beef cows. J. Am. Vet. Med. Assoc. 212:668-672.

Hoffman, L. C., M. Muller, S. W. P. Cloete, and D. Schmidt. 2003. Comparison of six crossbred lamb types: sensory, physical and nutritional meat quality characteristics. Meat Sci. 65:1265 1274.

Hopkins, D. L. and N. M. Fogarty. 1998. Diverse lamb genotypes 2. Meat $\mathrm{pH}$, colour and tenderness. Meat Sci. 49:477-488.

Hornikova, D., P. Herman, L. Mejsnar, J. Vecer, and J. Zurmanova. 2009. Creatine kinase structural changes induced by substrates. Biochimica et Biophysica Acta, 1794:270-274 http://eochemistry.wikispaces.com/The+Chemistry+of+Muscle +Contraction, assessed: $1^{\text {st }}$ March 2012.

Jacob, R. H., P. J. Walker, J. W. Skerritt, R. H. Davidson, D. L. Hopkins, J. M. Thompson, and D. W. Pethick. 2005. The effect of lairage time on consumer sensory scores of the $M$. Longissimus thoracis et lumborum from lambs and lactating sheep. Aust. J. Exp. Agric. 45:535-542.

Jacob, R. H., M. F. D`Antuono, G. M. Smith, D. W. Pethick, and R. D. Warner. 2007. Effects of lamb age and electrical stimulation on the colour stability of fresh lamb meat. Aust. J. Agric. Res. 58:374-382

Jose, C. G., D. W. Pethick and G. E. Gardner. 2008. Lipid peroxidation products inhibit Glutathione based protection of
Oxymyoglobin; a Model system. http://www.icomst.helsinki.fi/ ICoMST2008/CD\%20Papers/General\%20speakers+posters3p\%20papers/Session2/2A/2A.8.JOSE.pdf.

Kadim, I. T., O. Mahgoub, and W. Al-Marzooqi. 2008. Meat quality and composition of Longissimuss thoracis from Arabian camel (Camelus dromedaries) and Omani beef: A comparative study. J. Cam. Sci.1:37-47.

Kadim, I. T., O. Mahgoub, W. Al-Marzooqi, S. Khalaf, S. S. W. Al-Sinawi, and I. S. Al-Amri. 2009. Effects of transportation during the hot season and low voltage electrical stimulation on histochemical and meat quality characteristics of sheep longissimus muscle. Livest. Sci. 126:154-161.

Kannan, G., B. Kouakou, and S. Gelaye. 2001. Colour changes reflecting myoglobin and lipid oxidation in chevon cuts during refrigerated display. Small Rumin. Res. 42:67-745.

Kannan, G., T. H. Terrill, B. Kouakou, O. S. Gazal, S. Gelaye, E. A Amoah, and S. Samaké. 2000. Transportation of goats: effects on physiological stress responses and live weight loss. J. Anim. Sci. 78:1450-1457.

Kumar, M. and Y. Singh. 2010. Interpretation of water quality parameters for villages of sanganer tehsil, by using multivariate statistical analysis. J. Water Resource Prot. 2:860863

Lambertini, L., G. Vignola, A. Badiani, G. Zaghini, and A. Formigoni. 2006. The effect of journey time and stocking density during transport on carcass and meat quality in rabbits. Meat Sci. 72:641-646.

Liu, H. W., R. Z. Zhong, D. W. Zhou, H. X. Sun, and C. S. Zhao. 2012. Effects of lairage time after road transportation on some blood indicators of welfare and meat quality traits in sheep. J. Anim. Phys. Anim. Nutr. 96:1127-1135.

Lowe, T. E., C. J. Cook, J. R. Ingram, and P. J. Harris. 2001. Impact of climate on thermal rhythm in pastoral sheep. Physiol. Behav. 74:659-664.

Mach, N., A. Bach, A. Velarde, and M. Devant. 2008. Association between animal, transportation, slaughterhouse practices and meat $\mathrm{pH}$ in beef. Meat Sci. 78:232-238.

Mapiliyao, L., D. Pepe, U. Marume, and V. Muchenje. 2012. Flock dynamics, body and weight variation in sheep in two ecologically different resource-poor communal farming systems. Small Rumin. Res. 104:45-54.

María, G. A., T. Buil, G. Liste, M. Villarroel, C. Sanúdo, and J. L. Olleta. 2006. Effects of transport time and season on aspects of rabbit meat quality. Meat Sci. 72:773-777.

Martinezo-Cerezo, S., C. Sańudo, B. Panea, I. Medel, R. Delfa, I. Sierra, J. A. Beltran, R. Cepero, and J. L. Olleta. 2005. Breed, slaughter and ageing time effects on physio-chemical characteristics of lamb meat. Meat Sci. 69:325-333.

Mazzone, G., G. Vignola, M. Giammarco, A. C. Manetta, and L. Lambertini. 2010. Effects of loading methods on rabbit welfare and meat quality. Meat Sci. 85:33-39.

Melesse, A., S. Maak, R. Schmidt, and G. von Lengerken. 2011. Effect of long-term heat stress on some performance traits and plasma enzyme activities in Naked-neck chickens and their F1 crosses with commercial layer breeds. Livest. Sci. 141:227231.

Miranda-de la Lama, G. C., M. Villarroel, J. L. Olleta, S. Alierta, C. Sańudo, and G. A. María. 2009. Effect of the pre-slaughter logistic chain on meat quality of lambs. Meat Sci. 83:606-609. 
Miranda-de la Lama, G. C., L. Rivero, G. Chagón, S. GarciaBelenguer, M. Villarroel, and G. A. Maria. 2010a. Effect of the pre-slaughter logistic chain on some indicators of welfare in lambs. Livest. Sci. 128:52-59.

Miranda-de la Lama, G. C., M. Villarroel, G. Liste, J. Escos, and G. A. María. 2010b. Critical points in the chain of lambs in Spain that may compromise the animal's welfare. Small Rumin. Res. 90:174-178.

Miranda-de la Lama, G. C., P. Monge, M. Villarroel, J. L. Olleta, S. García-Belenguer, and G. A. María. 2011. Effects of road type during transport on lamb welfare and meat quality in dry hot climates. Trop. Anim. Health Prod. 43:915-922.

Miranda-de la Lama, G. C., M. Villarroel, and G. A. María. 2012. Behavioural and physiological profiles following exposure to novel environment and social mixing in lambs. Small Rumin. Res.103:158-163.

Mota-Rojas, D., M. Becerril, C. Lemus, P. Sánchez, M. González, S. A. Olmos, R. Ramírez, and M. Alonso-Spilsbury. 2006. Effects of mid-summer transport duration on pre-and postslaughter performance and pork quality in Mexico. Meat Sci. 73:404-412.

Muchenje, V., K. Dzama, M. Chimonyo, J. G. Raats, and P. E. Strydom. 2008. Meat quality of Nguni, Bonsmara and Aberdeen Angus steers raised on natural pasture in the Eastern Cape, South Africa. Meat Sci. 79:20-28.

Muchenje, V., K. Dzama, M. Chimonyo, P. E. Strydom, and J. G. Raats. 2009. Relationship between stress responsiveness and meat quality in three cattle breeds. Meat Sci. 81:653-657.

Ndou, S. P., V. Muchenje, and M. Chimonyo. 2011. Animal welfare in multipurpose cattle production systems and its implications on beef quality. Afr. J. Biotechnol. 10:1049-1064.

Partida, J. A., J. L. Olleta, M. M. Campo, C. Sañudo, and G. A. María. 2007. Effects of social dominance on the meat quality of young Friesian bulls. Meat Sci. 76:266-273.

Pollarda, J. C., R. P. Littlejohna, G. W. Ashera, A. J. T. Pearsea, J. M. Stevenson-Barrya, S. K. McGregora, T. R. Manleya, S. J. Duncana, C. M. Suttonb, K. L. Pollockb, and J. Prescottb. 2002. A comparison of biochemical and meat quality variables in red deer (Cervus elaphus) following either slaughter at pasture or killing at a deer slaughter plant. Meat Sci. 60:85-94.

Rani, Z. T., A. Hugo, and V. Muchenje. 2013. Perceptions of rural consumers on the quality of mutton in the Eastern Cape Province, South Africa. Sci. Res. Essays 8:921-931.

Radder, L. and R. Le Roux. 2005. Factors affecting food choice in relation to venison: A South African example. Meat Sci. 71:583-589.

Rodríguez, A. B., R. Bodas, R. Landa, O. Copez-Campos, A. R. Mantecon, and F. L. Giraldez, 2011. Animal performance, carcass traits and meat characteristics of Assaf and Merino $\mathrm{x}$ Assaf growing lambs. Livest. Sci. 138:13-19.

Rodríguez-Sánchez, J. A., G. Ripoll, S. Calvo, L. Ariño, and M. A. Latorre. 2009. The effects of seasonality of the growingfinishing period on carcass, meat and fat characteristics of heavy barrows and gilts. Meat Sci. 83:571-576.

Rosenvold, K. and H. J. Andersen. 2003. The significance of preslaughter stress and diet on colour and colour stability of pork. Meat Sci. 63:199-209.

Sainsbury, J., H. C. Schönfeld, and S. M. van Heerden. 2011. The nutrient composition of South African mutton. J. Food
Compost. Anal. 24:720-726.

Sańcheza, M., F. Canaliasa, T. Palenciab, and F. J. Gella. 1999. Creatine kinase 2 mass measurement: methods comparison and study of the matrix effect. Clin. Chim. Acta 288:111-119.

Sañudo, C., M. P. Santolaria, G. Maria, M. Osorio, and I. Sierra, I. 1996. Influence of carcass weight on Instrumental and Sensory lamb meat quality in intensive production systems. Meat Sci. 42:195-202.

SAS Institute. 2003. In: SAS/STAT Guide to Personal Computers, Version 6, Statistical Analysis System Institute Inc. Cary, NC.

Schoeman, S. J. 2000. A comparative assessment of Dorper sheep in different production environments and systems. Small Rumin. Res. 36:137-146.

Tadicha, N., C. Gallob, H. Bustamantea, M. Schwertera, and G. van Schaik. 2005. Effects of transport and lairage time on some blood constituents of Friesian-cross steers in Chile. Livest. Prod. Sci. 93:223-233.

Teixeira, A., S. Batista, R. Delfa, and V. Cadavez. 2005. Lamb meat quality of two breeds with protected origin designation. Influence of breed, sex, live weight. Meat Sci. 71:530-536.

Terlouw, C. 2005. Stress reactions at slaughter and meat quality in pigs: genetic background and prior experience. A brief review of recent findings. Livest. Prod. Sci. 94:125-135.

Terlouw, E. M. C. and P. Rybarczyk. 2008. Explaining and predicting differences in meat quality through stress reactions at slaughter: The case of Large White and Duroc pigs. Meat Sci. 79:795-805.

Toohey, E. S. and D. L. Hopkins. 2006. Eating quality of commercially processed hot boned sheep meat. Meat Sci. 72:660-665.

Van de Water, G., F. Verjans, and R. Geers. 2003. The effect of short distance transport under commercial conditions on the physiology of slaughter calves; $\mathrm{pH}$ and colour profiles of veal. Livest. Prod. Sci. 82:171-179.

Van Heerden, S. M., H. C. Schönfeldt, R. Kruger, and M. F. Smit. 2007. The nutrient composition of South African lamb (A2 grade). J. Food Compost. Anal. 20:671-680.

Veiseth-Kent, E., H. Grove, E. M. Færgestad, and S. O. Fjæra. 2010. Changes in muscle and blood plasma proteomes of Atlantic salmon (Salmo salar) induced by crowding. Aquaculture 309:272-279.

Vergara, H. and L. Gallego. 2000. Effect of electrical stunning on meat quality of lamb. Meat Sci. 56:345-349.

Vimiso, P. and V. Muchenje. 2013. A survey on the effect of transport method on bruises, $\mathrm{pH}$ and color of meat from cattle slaughtered at a South African commercial abattoir. S. Afr. J. Anim. Sci. 43:105-111.

Vojtic, I. 2000. Macro CK type 1 as a major component of serum creatine kinase activity in pregnant sheep. Small Rumin. Res. 35:249-253.

Wanatabe, A., C. C. Daly, and C. E. Devine. 1996. The effects of ultimate $\mathrm{pH}$ of meat on tenderness changes during ageing. Meat Sci. 42:67-78.

Warries, P., S. C. Kestin, C. S. Young, E. A. Bevins, and S. N. Bevins. 1990. Effects of pre-slaughter transport on carcass yield and indices of meat quality in sheep. J. Sci. Food Agric. 51:517-523.

Warriss, P. D., S. N. Brown, T. G. Knowles, J. E. Edward, P. J. Kettlewell, and H. L. Guise. 1998. The effect of stocking 
density in transit on the carcass quality and welfare of slaughter pigs: 2. Results from the analysis of blood and meat samples. Meat Sci. 50:447-456.

Webb, E. C. and O'Neill, H. A. 2008. The animal fat paradox and meat quality. Meat Sci. 80:28-36.

Wiklund, E., L. Johansson, and G. Malmfors. 2003. Sensory meat quality, $\mathrm{pH}$ values, blood parameters and carcass characteristics in reindeer (Rangifer tarandus tarandus L.) grazed on natural pastures or fed commercial feed mixture. Food Qual. Prefer. 14:573-581.
Yu, J., S. Tang, E. Bao, M. Zhang, Q. Hao, and Z. Yue. 2009. The effects of transportation on the expression of heat shock proteins and meat quality of $M$. longissimus dorsi in pigs. Meat Sci. 83:474-478.

Zimerman, M., G. Grigioni, H. Taddeo, and E. Domingo. 2011. Physiological stress responses and meat quality traits of kids subjected to different pre-slaughter stressors. Small Rumin. Res. 100:137-142. 